\title{
Six-minute Walk Test in Children with Cerebral Palsy: Comparing the Walking Distance between Different Level of Communication Function
}

\author{
Budiati Laksmitasari, Luh Karunia Wahyuni, Tirza Z Tamin
}

Department of Physical Medicine and Rehabilitation, Faculty of Medicine, University of Indonesia, Cipto Mangunkusumo Hospital, Jakarta, Indonesia

\begin{abstract}
Introduction: Children with cerebral palsy (CP), six-minute walk test (6MWT) is more difficult to perform because some children have communication impairment. The objective to study the distance of 6MWT among different level of communication in children with CP.

Methods: This study was cross-sectional study, in a Rehabilitation Clinic, on Juli to December 2018. The subjects were children aged 7-18 years old with cerebral palsy with Gross Motor Function Classification System (GMFCS) I-III, Communication Function Classification System (CFCS) I-III, able to walk independently with or without aid, and understand the instruction of 6MWT. All the subjects performed 6MWT. Level of communication function was evaluated by CFCS. The 6MWD between CFCS groups were compared.
\end{abstract}

Results: There were 23 subjects mean aged 9 years old, consisted of 17(73.9\%) male and 6(26.1\%) female, with GMFCS level I-III in sequence were 3(13\%), 11(47.8\%), and 9(39.1\%), also with CFCS level I-III in sequence were $5(21.7 \%), 7(30.4 \%)$, and $11(47.8 \%)$. Subjects with verbal communication were $14(60.9 \%)$ and nonverbal communication were $9(39.1 \%)$. The median of 6MWD in group with CFCS level I, II, and III respectively were 115 (60-282), 161 (17.5-281), and 135 (23-280) m. There was no significant difference in 6MWD between different groups of CFCS $(\mathrm{p}=0.960)$.

Conclusion: There were no difference in walking distance on 6MWT among different level of communication function in children with $\mathrm{CP}$.

Keywords: Cerebral palsy, Six-minute walk-test, Six-minute walking-distance, Communication Function Classification System (CFCS) 


\section{ABSTRAK}

Pendahuluan: Uji berjalan 6 menit (6MWT) lebih sulit dilakukan pada anak dengan cerebral palsy (CP), karena adanya gangguan komunikasi. Tujuan penelitian ini adalah untuk perbedaan jarang tempuh 6MWT pada anak CP yang memeliki gangguan fungsi komunikasi dengan tingkat yang berbeda

Metode: Penelitian ini menggunakan metode potong lintang, di sebuah klinik Rehabilitasi, pada JuliDesember 2018. Subjek adalah anak-anak usia 7-18 tahun dengan cerebral palsy dengan Gross Motor Function Classification System (GMFCS) I-III, Communication Functiom Classification System (CFCS) I-III, dapat berjalan sendiri dengan atau tanpa bantuan ambulatori, dan mengerti instruksi 6MWT. Semua subjek melakukan 6MWT. Level fungsi komunikasi dievaluasi dengan CFCS. 6MWT antara kelompok CFCS dibandingkan.

Hasil: Terdapat 23 subjek dengan nilai rata-rata 9 tahun, terdiri dari $17(73.9 \%)$ pria dan $6(26.1 \%)$ wanita, dengan GMFCS level I-III secara berurutan yaitu 3(13\%), 11(47.8\%), dan 9(39.1\%), juga dengan CFCS level I-III secara berurutan 5(21.7\%), 7(30.4\%), dan 11(47.8\%). Subjek dengan komunikasi verbal sebanyak 14(60.9\%) dan komunikasi sebanyak 9(39.1\%). Nilai tengah dari kelompok 6MWD dengan CFCS level I, II, dan III adalah 115 (60-282), 161 (17.5-281), dan 135 (23-280) m. Tidak terdapat perbedaan signifikan pada 6MWD antara kelompok CFCS yang berbeda $(\mathrm{p}=0.960)$.

Kesimpulan: Tidak terdapat perbedaan jarak tempuh pada anak CP dengan gangguan fungsi komunikasi yang berbeda.

Kata kunci: Cerebral palsy, Tes berjalan enam menit, Jarak berjalan enam menit, Sistem Klasifikasi Fungsi Komunikasi (CFCS)

\section{Correspondent Detail:}

\section{Budiati Laksmitasari}

Email: blaksmitasari@gmail.com

Faculty of Medicine University of Indonesia Jakarta, Indonesia

\section{INTRODUCTION}

Cerebral palsy $(\mathrm{CP})$ is the most common cause of physical disability in the children. ${ }^{1,2}$ Riset Kesehatan Dasar (RISKESDAS) 2010 reported prevalence of children aged 24-59 months with $\mathrm{CP}$ was $0.09 \% .^{3}$ Children with $\mathrm{CP}$ have lower physical fitness and aerobic capacity than healthy children. It can be caused by motor activation abnormalities and physical inactivity. ${ }^{4}$ Gross motor function of children with $\mathrm{CP}$, can be categorised into 5 different levels using a tool called the Gross Motor Function Classification System (GMFCS). (Table 1)

Children with $\mathrm{CP}$, exercise stress test can be performed to evaluate functional capacity and/ or prescribe the exercise intensity. ${ }^{5}$ 
Table 1. Gross Motor Function Classification System (GMFCS)

\begin{tabular}{cl}
\hline Level & \multicolumn{1}{c}{ Gross Motor Function } \\
\hline I & $\begin{array}{l}\text { Walks without restrictions, with } \\
\text { limitation for running and jumping }\end{array}$ \\
\hline II & $\begin{array}{l}\text { Walks with assistance from small } \\
\text { appliances and/or crutches, with slight } \\
\text { community ambulation limitations }\end{array}$ \\
\hline III & $\begin{array}{l}\text { Walks with the assistance of walker } \\
\text { and/or crutches, with community } \\
\text { ambulation difficulties }\end{array}$ \\
\hline IV & $\begin{array}{l}\text { Walks with the assistance of walker } \\
\text { but with limitations and requires a } \\
\text { wheelchair for community ambulation }\end{array}$ \\
\hline V & $\begin{array}{l}\text { Severely limited mobility, even with } \\
\text { appliances and adaptations, with } \\
\text { wheelchair adaptation required. }\end{array}$ \\
\hline
\end{tabular}

Cardiopulmonary exercise testing (CPET) is the gold standard for cardiorespiratory fitness test because it can directly measure the $\mathrm{VO}_{2}$ peak. ${ }^{6,7}$ When CPET is not feasible, submaximal or maximal stress test can be used as an alternative to predict $\mathrm{VO}_{2}$ peak. ${ }^{5}$ Six-minute walk test (6MWT) is one of a simple test with easy procedure and low cost. ${ }^{8}$ Guideline of 6MWT has been developed by American Thoracic Society (ATS), with sixminute walking distance (6MWD) as the main outcome. ${ }^{9}$ Several studies reported that $6 \mathrm{MWT}$ was reliable in children with ambulatory CP. ${ }^{10,11,12}$ Validity study by Leunkeu et al. reported high correlation between 6MWD and $\mathrm{VO}_{2}$ peak of $6 \mathrm{MWT}(\mathrm{r}=0.948, \mathrm{p}<0.001)$. It also reported significant correlation between $6 \mathrm{MWD}$ and $\mathrm{VO}_{2}$ peak of cycle ergometer $(\mathrm{r}=0.625, \mathrm{p}<0.05) .^{12}$

In children with disabilities, stress tests were more difficult to perform because some children have difficulty in receiving instructions, lack of motivation, low attention, or motor impairment. ${ }^{13}$ Communication function comprised the expressive and receptive component. An individual with receptive dysfunction may not understand even the simplest instruction. ${ }^{14}$ Communication impairment is common comorbidity in children with CP. Zhank et al. identified 55.15\% children with $\mathrm{CP}$ to have communication impairments. Of these, $32.3 \%$ were unable to communicate verbally. ${ }^{15}$ Study by Miguna et al. identified CFCS of children with $\mathrm{CP}$ in outpatient hospital setting. Among 36 subjects, 15 subjects were identified with CFCS level V, 8 subjects with CFCS level IV, 8 subjects with CFCS level III, 1 subject with CFCS level II, and 4 subjects with CFCS level I. ${ }^{16}$

Communication is defined as the process to exchange information and ideas, needs and desires. It requires sender and receiver, and each must be alert to the informational needs of the other to ensure that messages are conveyed effectively with the right intended meanings. ${ }^{17}$ Communication can be verbal or nonverbal. Verbal mean the communication use words and speech in sentences, phrase, or one word to send the messages. Nonverbal mean the communication may include vocalization, gesture, body movement, and writing. ${ }^{18}$ Study from the CP register of Western Sweden reported that half the children used speech, $32 \%$ used communication boards/books and $16 \%$ relied on body movements, eye gaze and sounds. ${ }^{19}$

Children with CP commonly have communication problem as a result of many factors. It can be directly caused by motor 
impairment and associated with cognitive and/or sensory processing deficits. ${ }^{18}$ Cerebral palsy may significantly affect tone, which in turn affects ability to use those muscles appropriately to perform the necessary movements for speech production, resulting in motor speech dysfunction, specifically dysarthria. ${ }^{20,21}$ Visual impairments can affect language development and interpersonal interaction. Hearing impairments affect speech development. Spoken and written language development of communication may also be affected by decreased of children interaction with their environment and limited activity. ${ }^{21}$ Language capacity depends on the level of motor, cognitive, and sensory abilities. ${ }^{18,19}$ Expressive language disorder was more associated with motor dysfunction whereas receptive language disorder was more related with cognitive problem in children with $\mathrm{CP} .{ }^{22}$ Nonverbal status and severe dysarthria in $\mathrm{CP}$ were associated with intellectual status. Previous study found that the proportion of intellectual impairment in children who able to produce one-word was significantly greater than children who able to use sentences. Most $(88 \%)$ of the nonverbal children had severe intellectual impairment. It also shows that only $24 \%$ children with severe dysarthria had normal intellectual level compared with $83 \%$ children with normal speech or mild dysarthria. ${ }^{18}$

Recently, overall communication and functional speech abilities in individuals with $\mathrm{CP}$ was classified at the level of activities and participation within the International Classification of Functioning, Disability and Health (ICF). The Communication Function Classification System (CFCS) classify overall communication effectiveness in everyday situations based on the individual's ability to act as both a sender and receiver of information, regardless of modalities used. ${ }^{20,23} \mathrm{CFCS}$ has five levels of communication abilities (Table 2). ${ }^{24}$

Table 2. Level of Communication Functiom Classification System for Cerebral Palsy

\begin{tabular}{cl}
\hline Level & \multicolumn{1}{c}{ Communication function } \\
\hline I & $\begin{array}{l}\text { Effective Sender and Receiver } \\
\text { with unfamiliar and familiar } \\
\text { partners. }\end{array}$ \\
\hline II & $\begin{array}{l}\text { Effective but slower paced Sender } \\
\text { and/or Receiver with unfamiliar } \\
\text { and/or familiar partners }\end{array}$ \\
\hline III & $\begin{array}{l}\text { Effective Sender and Receiver } \\
\text { with familiar partners }\end{array}$ \\
\hline IV & $\begin{array}{l}\text { Inconsistent Sender and/or } \\
\text { Receiver with familiar partners }\end{array}$ \\
\hline V & $\begin{array}{l}\text { Seldom Effective Sender and } \\
\text { Receiver even with familiar partners }\end{array}$ \\
\hline
\end{tabular}

The CFCS was designed to be applied to individuals across all ages without regard for developmental variables. ${ }^{20,23}$ The classification should be made by someone who is familiar with the child's everyday communication. This classification has been found to have very good test-retest reliability and moderate to strong inter-rater reliability. ${ }^{20}$ Hustad et al. reported reliability rate was $75 \%$ between two professional raters with $0.67 . .^{23}$

This study was intended to know the effect of communication function to the 6MWT performance. The objective of the study was to know whether different level of CFCS may cause significantly different walking distance (6MWD) in children with CP. 


\section{METHODS}

The study was performed on July to December 2018, at Yayasan Pembinaan Anak Cacat (YPAC)-Jakarta, Kitty Centre-Tamansari and Kitty Center-Sunter. All locations have the same characteristic as a center of children education and therapy at community setting. The subjects were children aged 7-18 years old with CP GMFCS I-III, CFCS I-III, able to walk independently with or without ambulatory aid, and understand the instruction of 6MWT. The subjects were excluded from the study if they had cardiorespiratory problem that could affect the walk test, severe intellectual disability, body mass index below 10 percentile or above 90 percentile, visual field or visual acuity problem that could not be corrected and could affect walking ability, severe hearing loss that could not be corrected, and moderate to severe pain on lower extremities. The subjects were recruited by consecutive sampling. The parents/guardian of the subjects who gave consent must fill out and sign the informed consent.

\section{Study Design}

The design was cross-sectional. Subjects who met the criterias, were assessed for some measurements by a medical doctor. Subjects were evaluated for gross motor function by GMFCS and communication function by CFCS. GMFCS and CFCS were assessed by direct observation and interview with the parent and/or guardian who were familiar with the subject.

\section{Measurement}

All the subjects were asked to perform 6MWT. Before performing the walk test, the parents/ guardian were informed about walk test preparation. Subjects must use comfortable clothes and footwear, bring their walking aid, get breakfast at least 2 hours before the test, not doing vigorous exercise at least 2 hours before the test. The walking tests were performed between 8 am and 12 am. The 15-m walking track was marked by a yellow ribbon that formed one straight line. A cone was placed at both ends of the walking track. A chair was placed near the start of the walking track.

The subjects were instructed to walk as far as possible on the track for 6 minutes. The assessor gave instruction continued by demonstration of $6 \mathrm{MWT}$ to the subjects until they understand. When subjects were performing the 6MWT, they were followed by the assessor from 1-2 meter behind them. During the test, assessor gave verbal encouragement at each minute of walking and 30 seconds and 15 seconds before the end of the test. The assessor told the subjects how much time had elapsed and the remaining time and gave scripted encouragement. At the end of the 6 minutes, the subject was told to stop. The distance walked was recorded as six-minute walking distance (6MWD). The walk test was terminated if the subjects had chest pain, severe dyspnoea, leg cramp, diaphoresis, pale skin or cyanosis.

\section{Statistical analysis}

Statistical analysis was carried out with SPSS for Windows version 20. Saphiro-Wilk was used to test the normality of variable distribution. To compare 6MWD between CFCS groups, one-way ANOVA would be used if the data distributions were normal, and Kruskal-Wallis would be used if the data distributions were not normal. The alpha level was $5 \%$. 


\section{RESULTS}

Total number of subjects in this study was 23 children. Subjects' characteristics were present in the table 3 . The median age was 9 (7-17) years old. Male subjects were 17(73.9\%), while female subjects were $6(26.1 \%)$. Based on topography of $\mathrm{CP}$, most subjects were spastic diplegic $12(52.5 \%)$. Other types were spastic hemiplegic in 3 subjects (13\%), spastic triplegic in 2 subjects $(8.7 \%)$, ataxic in 5 subjects $(21.7 \%)$, and one subject of mixed type (4.3\%). Subjects with GMFCS level II were most common, consist of 11 subjects $(47.8 \%)$, followed by GMFCS III (39.1\%), and GMFCS I (13\%).

Table 3. Characteristics of Subjects

\begin{tabular}{lccc}
\hline Characteristics & $\mathbf{N}$ & $\mathbf{\%}$ & $\begin{array}{c}\text { Median } \\
\text { (min-max) }\end{array}$ \\
\hline Age (years) & & & $9.0(7-17)$ \\
\hline Sex & & & \\
$\quad$ Male & 17 & 73.9 & \\
Female & 6 & 26.1 & \\
\hline Topography & & & \\
Spastic diplegic & 12 & 52.5 & \\
Spastic hemiplegic & 3 & 13 & \\
Spastic triplegic & 2 & 8.7 & \\
Dyskinetic & 0 & 0 & \\
Ataxic & 5 & 21.7 & \\
Mixed type & 1 & 4.3 & \\
\hline Verbal & & & \\
Communicator & 14 & 60.9 & \\
\hline Nonverbal & 9 & 39.1 & \\
Communicator & & & \\
\hline GMFCS level & & & \\
I & 3 & 13 \\
II & 11 & 47.8 \\
III & 9 & 39.1 & \\
\hline CFCS level & & & \\
I & 5 & 21.7 & \\
II & 7 & 30.4 & \\
\hline III & 11 & 47.8 & \\
\hline
\end{tabular}

In this study, 14 children (60.9\%) were verbal communicator whereas 9 children (39.1\%) were nonverbal communicator. According to communication function, subjects were dominated by CFCS level III which were 11 subjects (47.8\%), followed by CFCS II in 7 subjects (30.4\%), and CFCS I in 5 subjects (21.7\%). Of all subjects, the mean of 6 MWD was $134.3 \pm 80.3 \mathrm{~m}$. Normality test by Shapiro-Wilk identified 6MWD on CFCS subgroup as not normally distributed. Six-minute walking distance on each CFCS level was presented in table 4 .

Table 4. Six-minute walking distance (6MWD) based on CFCS level

\begin{tabular}{ccc}
\hline $\begin{array}{c}\text { CFCS } \\
\text { level }\end{array}$ & $\begin{array}{c}\text { Median of 6MWD } \\
(\mathbf{m i n}-\mathbf{m a x}) \mathbf{m}\end{array}$ & p-value \\
\hline I & $115(60-282)$ & \\
II & $161(17.5-281)$ & 0,960 \\
III & $135(23-280)$ & \\
\hline
\end{tabular}

Group of subjects with CFCS level II has the highest 6MWD 161 (17.5-281) m. Group with CFCS level III and level I, the median of 6MWD subsequently were 135 (23-280) $\mathrm{m}$ and 115 (60-282) $\mathrm{m}$. Comparison of 6MWD between CFCS level was analysed using KruskalWallis test. The analysis found no significant difference in 6MWD between different groups of CFCS $(p=0.960)$.

\section{DISCUSSION}

In this study, $39.1 \%$ subjects were nonverbal communicator. This is consistent with previous study by Zhank et al. that identified $32.3 \%$ 
children with $\mathrm{CP}$ were unable to communicate verbally. ${ }^{15}$ Most common CFCS level of all subjects was CFCS level III. Children with CFCS level III are effective sender and receiver with familiar partners. With this level, communication is not consistently effective with most unfamiliar partners, but is usually effective with familiar partners. ${ }^{24}$

The proportion of CFCS level in this study is not consistent with previous study by Miguna et al. Most common subjects in that study have CFCS level V. It can be caused by different study objective and inclusion criteria. The present study examined six-minute walk test in community setting. Therefore, the subjects must have certain level of gross motor and communication function. In the other side, Miguna et al. studied the correlation between GMFCS and CFCS in hospital setting. They included all level of gross motor and communication function. ${ }^{16}$ There were some studies that evaluated 6MWT in children with $\mathrm{CP}$, but none of those studies reported CFCS level. ${ }^{10,11,12}$

Most common topography of $\mathrm{CP}$ on previous study was spastic quadriplegic, which was not found in the present study. ${ }^{16}$ Some studies found that CFCS was significantly related with GMFCS. ${ }^{16,25}$ Children with spastic quadriplegic usually have the poorest gross motor function and mostly are unambulatory. ${ }^{26}$ This study only included subjects with CFCS level I to III to make sure that subjects can understand and follow the walk test instruction. Even though subjects with level III were not consistently received the information from unfamiliar partner, but the assessor was allowed to give the instruction and demonstration repeatedly until the subjects understand.

All subjects in present study could finish the 6MWT. The mean of 6MWD of all subjects was lower than previous studies. ${ }^{11,12,13}$ The shorter walking distance in present study may be caused by difference of subject's characteristics, difference of 6MWT procedure, or lower endurance level of subjects. The present and previous studies show that 6MWT is feasible to perform in children with $\mathrm{CP}$. The $6 \mathrm{MWT}$ can be an alternative of cardiorespiratory fitness test in children with $\mathrm{CP}$, as the 6MWD was significantly correlated with $\mathrm{VO}_{2}$ peak of cycle ergometer. ${ }^{12}$

In present study, statistical analysis found no significant difference of 6MWD between CFCS level. The walk test performance of children with disabilities may be affected by many factors, not only communication function but also cognitive function. Cerebral palsy, especially spastic types, are commonly accompanied by cognitive disorders including executive function, attention, and memory problem that can affect learning processes. ${ }^{27,28}$ Several factors may also cause variability of 6MWD in healthy subjects or patients with chronic diseases, such as sex, anthropometry, motor function, or motivation.Variability factors that caused by the walk-test procedure must be controlled optimally. ${ }^{9}$

Because the subjects were children with disabilities, 6MWT procedure in this study has undergone some modification. The assessor gave demonstration of 6MWT procedure to the subjects until they understand. It is one of the modelling methods. Study by Tamin also used modelling method for 6MWT in children with 
intellectual disabilities. ${ }^{13}$

During the walk-test, assessor behind subjects was informing the remaining time and giving verbal encouragement at certain times. This verbal encouragement was also used by previous studies about 6MWT in children with intellectual disabilities ${ }^{13}$ and children CP. ${ }^{10,11,12}$ It is one of prompting method and complies with the $6 \mathrm{MWT}$ guideline by ATS. ${ }^{9}$ Children with intellectual disability or communication problem need longer learning process, more repetition, and adaptation according to their learning ability. ${ }^{27}$ Modification of 6MWT procedure such as modelling and prompting method may improve the ability of the subjects with intellectual or communication problem to understand and perform the walk-test instructions.

This is the first study that aimed to know the effect of communication function on 6MWD in children with CP. The other strength of this study is the use of methods to overcome difficulty of performing 6MWT in children with disabilities. This study also tried to control other factors that may be potential to affect 6MWD by limiting subject inclusion.

There were some weaknesses of present study. First, the cognitive and communication function were not specifically assessed. The future study should assess all component of cognitive and communication function that may affect the walk test performance. Second, this study did not analyse the effect of other factors other than communication function to 6MWD. To know the effect of communication to the 6MWD, another method of statistical analysis can be used, such as multiple regressions of several potential factors.

\section{CONCLUSION}

The 6MWT was feasible for children with CP. There was no significant difference of walking distance between subjects with different level of communication function. Different level of communication function may not become an issue that could affect $6 \mathrm{MWT}$ performance in $\mathrm{CP}$ children with CFCS level I-III.

\section{REFERENCES}

1. Hoare B, Ditchfield M, Thorley M, et al. Cognition and bimanual performance in children with unilateral cerebral palsy: protocol for a multicentre, cross-sectional study. BMC Neurol. 2018;18(1):63. doi:10.1186/s12883-018-1070-z

2. Christensen D, Van Naarden Braun $\mathrm{K}$, Doernberg NS, et al. Prevalence of cerebral palsy, co-occurring autism spectrum disorders, and motor functioning - Autism and developmental disabilities monitoring network, USA, 2008. Dev Med Child Neurol. 2014; 56(1): 59-65.

3. Situasi penyandang disabilitas. Buletin Jendela Data \& Informasi Kesehatan, semester 2. Kementerian Kesehatan Republik Indonesia.; 2014.

4. Nsenga AL1, Shephard RJ, Ahmaidi S. Aerobic training in children with cerebral palsy. Int J Sports Med. 2013;34(6):5337. doi: $10.1055 / \mathrm{s}-0032-1321803$.

5. Ng QX, Ho CYX, Chan HW, Yong BZJ, Yeo WS . Managing childhood and adolescent attention-deficit/hyperactivity 
disorder (ADHD) with exercise: A systematic review. Complement Ther Med. 2017 ;34:123-128. doi: 10.1016/j. ctim.2017.08.018.

6. Den Heijer AE, Groen Y, Tucha L, Fuermaier AB, Koerts J, Lange KW, Thome J, Tucha O. Sweat it out? The effects of physical exercise on cognition and behavior in children and adults with ADHD: a systematic literature review. J Neural Transm (Vienna). 2017;124(Suppl 1):3-26. doi: 10.1007/s00702-016-15937.

7. Rowland TW. Cardiopulmonary exercise testing in children and adolescents. American College of Sports Medicine, North American Society for Pediatric Exercise Medicine, editors. Champaign: Human Kinetic; 2018. p. 205-13.

8. Verschuren O, Ketelaar M, Keefer D, Wright V, Butler J, Ada L, et al. Identification of a core set of exercise tests for children and adolescents with cerebral palsy: a Delphi survey of researchers and clinicians. Dev Med Child Neurol. 2011 ; 53(5): 449-56.

9. Hassan J, van der Net J, Helders PJ, Prakken BJ, Takken T. Six-minute walk test in children with chronic conditions. Br J Sports Med. 2010; 44(4):270-4.

10. Fitzgerald D1, Hickey C, Delahunt E, Walsh M, O'Brien T. Six-Minute Walk Test in Children With Spastic Cerebral Palsy and Children Developing Typically. Pediatr Phys Ther. 2016; 28(2):192-9. doi: 10.1097/PEP.0000000000000224.

11. Slaman J1, Dallmeijer A, Stam H,
Russchen H, Roebroeck M, van den Berg-Emons R. The six-minute walk test cannot predict peak cardiopulmonary fitness in ambulatory adolescents and young adults with cerebral palsy. Arch Phys Med Rehabil. 2013;94(11):2227-33. doi: 10.1016/j.apmr.2013.05.023.

12. Leunkeu AN, Shephard RJ, Ahmaidi S. Six-minute walk test in children with cerebral palsy gross motor function classification system levels I and II: reproducibility, validity, and training effects. Arch Phys Med Rehabil. 2012; 93(12): 2333-9.

13. Tamin TZ. Keterandalan uji jalan 6 menit di lintasan empat persegi panjang pada penyandang disabilitas intelektual dengan obesitas di Jakarta. Journal Indonesia Assoc. 2011; 61(8).

14. Zhang JY, Oskoui M, Shevell M. A Population-based study of communication impairment in cerebral palsy. Journal of Child Neurology. 2015; 30(3): 277-84.

15. Miguna VM, Prananta MS, Alam A. Correlation between gross motor function classification system and communication function classification system in children with cerebral palsy. AMJ. 2017; 4(2): $221-7$.

16. Choi JY, Park J, Choi YS, Goh YR, Park ES. Functional Communication Profiles in Children with Cerebral Palsy in Relation to Gross Motor Function and Manual and Intellectual Ability. Yonsei Med J. 2018;59(5):677-685. doi: 10.3349/ ymj.2018.59.5.677.

17. Sigurdardottir S, Vik T. Speech, 
expressive language, and verbal cognition of preschool children with cerebral palsy in Iceland. Dev Med Child Neurol .2011; 53: 74-80.

18. Himmelmann K, Lindh K, Hidecker MC. Communication ability in cerebral palsy: A study from the $\mathrm{CP}$ register of western Sweden. European Journal of Paediatric Neurology. 2013; 17(6): 568-74.

19. Cockerill H. Classifying communication ability in cerebral palsy. Dev Med Child Neurol. 2016;58(2):117-8. doi: 10.1111/ dmen.12863.

20. Watson RM, Pennington L. Assessment and management of the communication difficulties of children with cerebral palsy: a UK survey of SLT practice. Int J Lang Commun Disord. 2015;50(2):241259. doi:10.1111/1460-6984.12138

21. Vos RC, Dallmeijer AJ, Verfoef M, et al. Developmental trajectories of receptive and expressive communication in children and young adults with cerebral palsy. Dev Med Child Neurol. 2014; 56(10): 951-9. Available at: doi: 10.1111/dmcn.12473. Accessed on August 25, 2019.

22. Hidecker MJC, Slaughter J, Abeysekara P, Ho NT, Dodge N, Hurvitz EA. Early Predictors and Correlates of Communication Function in Children With Cerebral Palsy. J Child Neurol. 2018;33(4):275-285. doi: $10.1177 / 0883073817754006$.

23. Hidecker MJC, Paneth N, Rosenbaum PL, Kent RD, Lillie J, Beulenberg J, et al. Developing and validating the communication function classification
System for individuals with cerebral palsy. Dev Med Child Neurol. 2011; 53(8): 704-10.

24. Compagnone E, Maniglio J, Camposeo S, Vespino T, Losito L, De Rinaldis M. Functional classifications for cerebral palsy: Correlations between the gross motor function classification system (GMFCS), the manual ability classification system (MACS) and the communication function classification system (CFCS). Research in Developmental Disabilities. 2014; 55: 2651-7.

25. Hemsley B, Kuek M, Bastock K, Scarinci N, Davidson B. Parents and children with cerebral palsy discuss communication needs in hospital. Dev Neurorehabil. 2013;16(6):363-74. doi: $10.3109 / 17518423.2012 .758187$.

26. Javan AT, Framarzi S, Abedi A, Nattaj FH. Effectiveness of rhythmic play on the attention and memory functioning in children with mild intellectual disability. International Letters of Social and Humanistic Sciences. 2014; 17: 9-21.

27. Bodimeade HL, Whittigham K, Lloyd $\mathrm{O}$, Boyd RN. Executive functioning in children and adolescents with unilateral cerebral palsy. Dev Med Child Neurol. 2013; 55: 926-33.

28. Goemans N, Klingels K, van den Hauwe M, Boons S, Verstraete L, et al. Sixminute walk test: reference values and prediction equation in healthy boys aged 5 to 12 years. PLoS ONE. 2013; 8(12): e84120. 